\title{
Problematika vyjadřování a hodnocení nefigurativní malby emocí u jedenáctiletých: didaktická analýza
}

\author{
Non-objective art expression concepts of emotion by five grades pupils: didactic analysis
}

\author{
Jindřich Lukavský
}

\begin{abstract}
Abstrakt: Př́ispěvek informuje o zjištěních z výzkumu nefigurativního výtvarného vyjádření pojmů emocí u dětí pátých ročníků ZŠ. Základní výzkumné otázky zní: Jak vysvětlit rozdíly v hodnocení provedeném žáky a kontrolní expertní skupinou? Lze vysvětlit pravidelnosti v interpretaci a hodnocení u žáků a expertů? Výzkum kombinuje kvalitativní metodiku analýzy $\mathrm{s}$ jednoduchými statistickými funkcemi. Na konkrétním př́ikladě hodnocení žákovské malby je vyložen fenomenologický model estetického zážitku, který tvoří interpretační rámec př́stupu k obsahům díla. Cílem je lepší porozumění vztahů mezi fungováním expertního výtvarného díla ve vizuální kultuře a funkcemi žákovského díla $\mathrm{v}$ pedagogickém procesu výtvarné výchovy ve škole.
\end{abstract}

Klíčová slova: hodnocení ve výtvarné výchově, typy estetického zážitku, konceptová analýza

\begin{abstract}
The paper informs about partial conclusions from research of non-objective art expression concepts of emotion by five grades pupils. The based research issues are: How can we explain differences between assessment of pupils and experts? Is it possible to explain regularity in interpretation and assessment in pupils and experts? Research combines qualitative method of analysis with simple statistic functions. In particular example of assessment pupil's painting is explained phenomenological model of esthetic experience. It functions as interpretative frame for access to art work contents. The goal is to better understand functions of pupil's art work in education and expert work in visual culture.
\end{abstract}

Keywords: assessment in visual culture art education, types of esthetic experience, conceptual analysis

\section{Východiska výzkumu}

Problematika hodnocení v expresivně tvůrčích disciplínách, potažmo také ve výtvarné výchově, je výzvou pro učitele při reflexi jeho pojetí výuky a zvládání didaktického metajazyka (Slavík, Janík 2007). V mnoha výukových situacích jsou u žáků trénovány tzv. faktické rozhodovací mechanismy, která se týkají „nalezení pravdy“ a tedy mají za cíl jednání, které je prospěšné za dodržení nějakého vnějšího pravidla. Oproti tomu expresivně tvưrčí činnosti, jejich reflexe a interpretace fungují spíše na bázi tzv. adaptivních egocentrických rozhodnutí, které se týkají zainteresovanosti subjektu na situaci (Goldberg 2004, s. 94). Proto jsou hodnotící soudy o výtvarných dílech nebo žákovské produkci často mylně považovány za svrchovanou záležitost osobní preference. Takový stav by ovšem neumožňoval, aby se postoj k dílu a samo hodnocení stávalo předmětem žákovského učení. Při pokusu o nalezení přístupu, který zohledňuje jak faktické kvality díla, tak zainteresovanost subjektu $\mathrm{v}$ zážitku $\mathrm{z}$ díla, vyjdeme $\mathrm{z}$ teorie fenomenologické estetiky a jejího modelu estetického zážitku. Usuzovat na typ zážitku budeme $\mathrm{z}$ výsledků hodnocení prováděných $\mathrm{v}$ rámci modelové výzkumné situace. 


\section{Realizační podoba výzkumu}

Tato modelová situace aranžuje expresivně tvořivý úkol ve výtvarné výchově. Jedná se o typ výtvarných aktivit využívaných např́ič jednotlivými stupni vzdělávání ${ }^{1}$. Na tabuli je napsáno sedm pojmů emočních stavů: smutek, úzkost, zoufalství, zlost, naděje, štěstí, radost. Žáci jsou vyzváni, aby si vybrali jeden z nich, který se stane námětem pro jejich výtvarnou tvorbu. Dále jsou instruováni, aby svoje rozhodnutí neprozrazovali spolužákům a zapsali jej na zadní stranu čtvrtky. Výtvarnou technikou určenou ke ztvárnění námětu je nefigurativní malba a důraz je při zpracování kladen jednak na výstižnost a jednak na kvalitu produkce. Tato pravidla zakládají ambivalentní jádro výtvarného úkolu, které na straně jedné předpokládá usilovat o zrretelnou artikulaci autorské intence a na druhé straně se pokusit o neotřelé, hodnotné ztvárnění. Po výtvarné tvorbě následuje reflektivní část. Žákům jsou postupně představena vzniklá díla a oni do předem připravených dotazníků vyplňují ke každému $\mathrm{z}$ nich následující údaje: předpokládaný námět díla, hodnocení díla vyjadřované na škále od 1 do 5 (analogie školní klasifikace) a důvody, které vedly k hodnocení. Reflektivní část týkající se vzniklého souboru žákovských prací je v další fázi výzkumu zopakována s kontrolní expertní skupinou, kterou tvoří studenti učitelských oborů výtvarné výchovy na FPE ZČU v Plzni.

\section{Vzorek a historie výzkumu}

Výzkum je v nezměněném pojetí opakovaně realizován $\mathrm{v}$ několikaletých nepravidelných intervalech od roku 1987. V textu publikované výsledky znovu zpracovávají data shromážděná ve dvou školách v Praze a v Plzni v roce 2006 a diplomovou prací J. Průši z roku 2009. Výběrová strategie žáků je prováděna účelově, dle dostupnosti. Základní vzorek tvořily 3 základní školy, respektive 4 páté tř́ídy. Do výzkumu se zapojilo 90 žáků (21 dívek, 69 chlapců). Kontrolní skupinu tvořilo 30 studentů 2. a 3. ročníku Učitelství výtvarné výchovy pro střední školy (20 dívek, 10 chlapců).

Předchozí výzkumná zjištění publikovaná v roce 2006 (Slavík \& Lukavský 2006) představila především preference volených námětů, kontingenci zamýšlených a rozpoznávaných námětů, faktorovou analýzu identifikující hlavní vlivy uplatňující se při zpracování námětu a jeho následném rozpoznávání. Aktuální př́spěvek se zaměřuje na problematiku ponoru a odstupu od posuzovaného díla. Opírá se o kategorizaci hodnotících výroků (celkem kategorizováno 2110 dat) a představuje výkladový rámec estetického zážitku.

\section{Metodika výzkumu}

Metodika výzkumu vychází z konceptové analýzy, v níž se na základě pozorování výuky rozebírá významová struktura a sociální nebo kulturní kontexty vzdělávacího obsahu (Slavík, Dytrtová, \& Fulková, 2010). V našem konkrétním př́ípadě se podkladem pro konceptovou analýzu stávají reflektivní výroky, které se vztahují k vytvořeným artefaktům (malbám žáků). Cílem analýzy je explikace vzdělávací praxe s oporou o teorii a empirický výzkum prostřednictvím rozpoznaných obsahových struktur, resp. konceptů. Speciálně jde o hlubší porozumění estetickému zážitku, respektive schopnosti recipientů reflektovat obsahovost vlastního postoje zaujímaného $\mathrm{k}$ hodnocenému dílu. Jsou srovnávány rozdíly mezi dispozicemi jedenáctiletých žáků a expertní skupiny.

\footnotetext{
${ }^{1}$ Srovnej např. Poupa a Voseček (1983); Macko a Nevřelová (1987); př́íklady současných výtvarných úkolů: http://www.msnavysinach.cz/index2.htm; http://www.skolaraspenava.cz/dokument/svp/574.pdf
} 


\section{Př́ípad Smutek}

Nejvhodnější pro představení zjištěných rozdílů mezi žákovskými posuzovateli a expertní skupinou je volba extrémního př́ípadu. Zamýšleným námětem hodnoceného díla (představuje jej obrázek 1.) byl „Smutek“. Shodným rysem v hodnocení u obou skupin bylo to, že dílo bylo identifikováno jako „negativní emoce. Podstatné rozdíly se ovšem týkaly interpretačního rozptylu a hodnocení kvality díla.

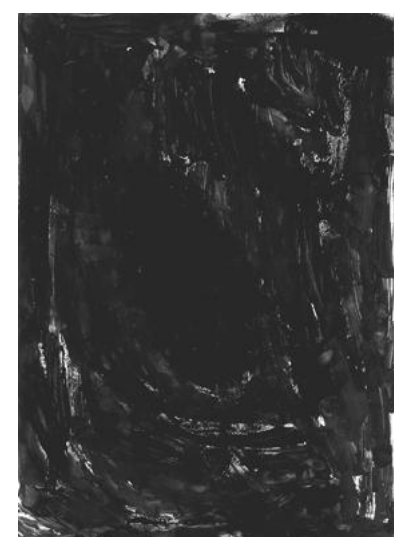

Obrázek 1. 62/10, dívka, Smutek

Žákovské interpretace se většinou sjednocovaly na identifikaci námětu coby „Zlosti“ (14 voleb), pouze dva recipienti jej vyhodnotili jako „Smutek“. Námět díla byl takřka nerozpoznán a navíc bylo dílo hodnoceno negativně průměrnou známkou 3,94. Členové expertní skupiny nejčastěji tipovali za námět díla „Úzkost“ (3 volby), dále „Zlost“" (2 volby) a „Smutek“ a „Zoufalství“ obdržely jednu volbu. Na rozdíl od žákovské skupiny však experti hodnotili dílo kladně průměrnou známkou 1,43 (šestkrát hodnocení 1 , jednou hodnocení 4 ). Podrobnosti o hodnocení a hodnotících výrocích zachycují tabulka 1 a tabulka 2. První tři řádky obou tabulek zaznamenávají převažující hodnotící tendenci, poslední řádka potom výjimečný prŕípad. Hodnotící kritéria recipientů z obou skupin jsou velmi komplexní. Zdá se, že problém hodnocení bude záviset spíše na kvalitě zážitku z díla, než na registrování jeho dílčích vlastností.

Tabulka 1

Přiklady žákovského hodnocení

\begin{tabular}{|l|l|l|l|}
\hline Index & Známka & Identifikace & Hodnotící soud \\
\hline $55 / 3$ & 5 & zlost & nelíbí, je tam moc černé barvy \\
\hline $51 / 5$ & 5 & zlost & je tam moc černé barvy \\
\hline $59 / 6$ & 5 & zlost & hnusný začmáraný a moc černý a nevýrazný \\
\hline $49 / 16$ & 1 & zlost & je to strašidelné \\
\hline
\end{tabular}

Pozn. sloupec Index vyjadřuje identifikační údaje respondenta.

Tabulka 2

Přiklady expertního hodnocení

\begin{tabular}{|l|l|l|l|}
\hline Index & Známka & Identifikace & Hodnotící soud \\
\hline $157 / 55$ & 1 & zlost & dobrá zlost, emotivní \\
\hline $153 / 55$ & 1 & zlost & + zaplnění papíru \\
\hline $159 / 55$ & 1 & zoufalství & $\begin{array}{l}\text { ačkoli jde o monochromní práci, cítím prostor, } \\
\text { pŕíjemné }\end{array}$ \\
\hline $156 / 55$ & 4 & úzkost & strohé \\
\hline
\end{tabular}

Pozn. sloupec Index vyjadřuje identifikační údaje respondenta. 


\section{Estetický postoj a zážitek}

Již dř́ve byl v souvislosti s hodnocením vyjádření emocí nefigurativní malbou rozlišen deduktivní a induktivní postoj diváka (Slavík \& Lukavský, 2006). Estetický zážitek, který je jimi ovlivněn, je charakteristický oscilací mentální aktivity mezi reflektujícím a reflektovaným já. Tento rozštěp self vytváŕi estetickou distanci (podrobně o estetickém zážitku Zuska, 2001). Změna distance působí změnu kvality estetického zážitku a hodnocení díla. Možné typy estetického zážitku si stručně představíme a doprovodíme prototypickými hodnotícími výroky.

\section{Typy estetického zážitku}

\subsection{Poddistancování}

Poddistancování nastane, pokud dojde ke zborcení napětí mezi reflektujícím a reflektovaným já a subjekt se dostává do dimenze rovnocenné a funkčně identické s estetickým objektem. $\mathrm{K}$ němu se potom vztahuje jako $\mathrm{k}$ něčemu „reálně“ zažívanému. Přestává být důležité rozlišení mezi fantazií a realitou, obojí je takřka stejně intenzivní. Př́́klady poddistancování: 132/2 „vyvolává smutný pocit, melancholii, dálku; jako když někomu někdo chybí, kdo je daleko“, 109/9 „barvy stylizovaného slunce a dalších "př́jemných" tvarů jsou zde natolik pozměněné a znepokojující, že dostávám pocit jako, že na mě obraz útočí, nic mě neutěší“.

\subsection{Zaujetí optimálni estetické distance}

Pro zaujetí optimální distance je na straně subjektu potřeba vyvinout určitou míru kulturního úsilí, při překonávání kvalit objektového pólu, které mohou být zpočátku pocit’ovány nebo tematizovány jako nepř́ijemné. Např́íklad při vnímání obrazu, který metaforicky vyjadřuje smutek a jeví se jako ohrožující, musí jedinec překonat reakce, které toto vyhodnocení zajišt’ují ne na ,úrovni reflektovaného vědomí a prožívání, ale v základnějších (vývojově) vitálních vrstvách vědomí, neurofyziologicky v mozkovém kmeni a tzv. retikulárním aktivizačním systému.“ (Zuska, 2001, s. 55). Příklady výroků ilustrujících pohyb autora v intencích optimální estetické distance: 138/12 „Čím déle ho sleduji tím je pro mě zajímavější. Zejména rozdělení obrázku na 2 části. Lze na něm vidět určitý vývoj. Postupně mě nadchnul.“, 132/14 ,pokud počítám s tím, že je to zlost, myslím si, že je tato emoce dobře vyjádřena agresivními tahy a zakalenou, temnou barvou ---> proto taky tak nepř́ijemně působí".

\subsection{Předistancování}

K předistancování a $\mathrm{k}$ vykročení $\mathrm{z}$ rámce estetického zážitku může nastat v případě, kdy dojde $\mathrm{k}$ přepětí kontaktu mezi reflektovaným já a estetickým objektem. K předistancování na rozdíl od poddistancování nedochází z intence subjektu, ale „záleží velkou měrou také na estetickém objektu a jeho bázi.“ (Zuska 2001, s. 54). Pokud je objekt příliš komplexní, a je vyžadováno nadměrné soustředění pozorovatele, nedojde $\mathrm{k}$ vytvoření estetického objektu. Př́íklady předistancování: 35/24, „čmáranice“, 15/10 „pláskanice“.

\subsection{Přechýlení}

Jestliže dojde z nějakého důvodu k přemístění pozornosti reflektovaného já na jiný estetický objekt. K tomuto přechýlení zaměřenosti na jiný estetický objekt zpravidla dochází, pokud 
stávající estetický objekt evokuje vzpomínku na zážitek z osobního života a její výrazová struktura se stává hlavním předmětem zájmu subjektu. Vnímatel se již nezabývá strukturou původního objektu a předpisem, který generuje, ale zpracovává strukturu novou původním objektem asociovanou. V reálné situaci to zpravidla znamená hladký přesun pozornosti vnímatele a interpreta $\mathrm{z}$ uměleckého díla na osobní historii, přičemž se stává, že se interpretace vzdaluje $\mathrm{z}$ oblasti relativního sjednocování soudů do oblasti autonomních s velkým individuálním rozptylem. Př́klady přechýlení: 144/50 ,--> prŕíjemný zážitek z prázdnin, hezké vzpomínky“, 63/15 „Filip“.

\subsection{Zborcení}

Posledním př́padem, který může nastat při pokusu o zaujetí estetické distance, je její zborcení. To může nastat, jestliže se objekt nabízející se pro estetické vnímání disponuje př́liš chudým komplexem estetických kvalit, které nejsou s to vtáhnout subjekt do estetické distance po potřebný čas. Zborcení estetické distance nastává také v momentě, kdy objekt emituje vlastnosti, které do značné míry potlačují nebo prímo znemožňují nastolení estetické funkce. Mohou působit na úrovni fyziologie (např́iklad zprostředkovaný zážitek bolesti, s nímž pracuje body art), nebo v oblasti náboženských a sociálních tabu (zobrazení nepřijatelných témat, např́klad díla z kontroverzní výstavy Decadence Now! v Galerii Rudolfinum).

\section{Závěry}

Vrat'me se nyní k případu Smutek, který posloužil pro demonstraci rozdílných přístupů mezi žákovskou a expertní skupinou. Co se týká rozpoznání námětu, vyjadřují se žáci překvapivě homogenně, ale identifikují námět coby zlost. To zdánlivě neznamená nic překvapujícího. Např́klad Nelson Goodman ve svém prŕíspěvku k expresivismu v estetice upozorňuje: „,... vyvolané emoce jsou zřídkakdy ty, které jsou vyjádřeny. Zmučený výraz vzbuzuje spíše soucit než bolest a tělo vyjadřující nenávist a hněv vzbuzuje častěji odpor či strach.“ (Goodman, 2007, s. 52). Zdá se, že u žáků nejprve dochází k přechýlení distance. Zlost, kterou pocit’ují nad smutným obrázkem postupně zaujímá místo objektového pólu estetického zážitku. Metaforicky smutný obrázek, který překáží prožitku pohody, zkrátka rozčiluje. Známka 5 , jenž v žákovském hodnocení převažuje ( 8 voleb) zároveň symbolicky vyjadřuje maximální možnou míru distance. Nelibost je potvrzena odstupem a dochází ke zborcení estetického zážitku. Pouze jediná žákyně si dokáže vychutnat „strašidelnost“ obrázku. Oproti tomu s metaforicky úzkostným, nebo depresivním vyzněním obrázku nemá expertní skupina problém (taktéž na jedinou výjimku). Studenti jsou schopni udržet optimální distanci od podnětu zpočátku pocit’ovaného jako nepř́ijemný. V normální situaci výuky by se podobný objevený rozdíl měl stát předmětem sociokognitivního konfliktu a následně předmětem žákovského učení. Schopnost rozvoje dispozic ke vstupu do estetické distance je zásadním předpokladem plnohodnotného estetického zážitku. Přitom nejde jen o schopnost reflektování kvality objektu na úrovni reflektovaného já, ale především o schopnost sebereflexe na úrovni reflektujícího já. Zpř́stupnění právě takových typů obsahů by měl učitel pomoci svým žákům zajistit. 


\section{Literatura}

Goldberg, E. (2004). Jak nás mozek civilizuje. Praha: Karolinum.

Goodman, N. (2007). Jazyky umění: nástin teorie symbolio. Praha: Academia.

Průša, J. (2009). Sledováni nefigurativniho výtvarného projevu u žáků 5. tř́d (Diplomová práce). Plzeň: FPE

Slavík, J., Dytrtová, K., \& Fulková, M. (2010). Konceptová analýza tvořivých úloh jako nástroj učitelské reflexe. Pedagogika, 60(3/4), 223-241.

Slavík, J., \& Janík, T. (2007). Fakty a fenomény v průniku didaktické teorie, výzkumu a praxe vzdělávání. Pedagogika, 57(3), 263-274.

Slavík, J., \& Lukavský, J. (2006). Didaktická analýza nefigurativního výtvarného vyjádření pojmů emocí u jedenáctiletých dětí. In Současné metodologické př́stupy a strategie pedagogického výzkumu. Sbornik anotaci 14. konference ČAPV. Plzeň: ZČU v Plzni.

Zuska, V. (2001). Estetika. Úvod do současnosti tradiční discipliny. Praha: Triton.

\section{Kontakt}

Mgr. Jindřich Lukavský

Západočeská univerzita v Plzni

Fakulta pedagogická, Katedra výtvarné kultury

Chodské nám. 1, 30614 Plzeň

e-mail: lukajda@kvk.zcu.cz

\section{Bibliografické údaje}

Lukavský, J. (2011). Problematika vyjadřování a hodnocení nefigurativní malby emocí u jedenáctiletých - didaktická analýza. Představy budoucích pedagogů o hodnotách výchovy a vzdělávání. In T. Janík, P. Knecht, \& S. Šebestová (Eds.), Smísený design v pedagogickém výzkumu: Sbornik př́spěvkĩ z 19. výročni konference České asociace pedagogického výzkumu (s. 316-321). Brno: Masarykova univerzita.

Dostupné z: http://www.ped.muni.cz/capv2011/sbornikprispevku/lukavsky.pdf doi: 10.5817/PdF.P210-CAPV-2012-35 